\title{
Razvoj prehrambenih studija: doprinosi sociologije, kulturne antropologije, etnologije i povijesti
}

\author{
JELENA IVANIŠEVIĆ \\ MELANIJA BELAJ \\ Institut za etnologiju i folkloristiku, Zagreb
}

\begin{abstract}
U radu se daje pregled relevantnih kulturnoantropoloških, etnoloških, socioloških i povijesnih istraživanja prehrane koja su utjecala na razvoj prehrambenih studija, platforme koja okuplja istraživanja kulture prehrane iz različitih očišta znanstvenih disciplina i subdisciplina. Kroz rad se također ukazuje na sve prisutniju nemogućnost pisanja o prehrani isključivo u okrilju jedne znanstvene discipline te u tom smislu na potrebu interdisciplinarnih istraživanja fenomena prehrane u različitim kontekstima.
\end{abstract}

Ključne riječi: prehrambeni studiji, prehrana, etnološka i kulturnoantropološka istraživanja prehrane, sociološka istraživanja prehrane, povijesna istraživanja prehrane

Uvidi u problematiku prehrane danas dolaze iz raznorodnih znanstvenih disciplina i polja, od filozofije, povijesti, sociologije, etnologije, antropologije do nutricionističkih/medicinskih, agronomskih ili marketinških i turističkih istraživanja. Golem porast interesa za prehrambene teme s različitih istraživačkih perspektiva otvara pitanja o dosegu, sadržaju i metodama, kao i pitanje o prirodi "prehrambenih studija", njihovoj društvenoj i intelektualnoj poziciji. Termin prehrambeni studiji prvi je put u nas upotrijebljen u doktorskoj disertaciji Od kuharice do književnosti; hrvatski kulinarski i gastronomski narativi (Ivanišević 2014). Osim toga, manjak domaće literature o prehrambenim istraživanjima podrazumijeva i izostanak stručne rasprave o imenovanju novog interdisciplinarnog područja koje okuplja istraživače društvenih, humanističkih, ali i prirodnih znanosti, tako da je termin prehrambeni studiji nastao u nastojanju da se pronađe hrvatski ekvivalent lako skovanom engleskom terminu food studies, koji obuhvaća istraživanja prehrane u najširem smislu. Budući da se u recentnoj literaturi tim pojmom obuhvaća doista širok raspon pristupa različitih znanstvenih disciplina, a bez zajedničkog teorijskog i metodološkog okvira, "prehrambeni studiji" podrazumijevaju kišobranski termin kojim se nastoji imenovati novo i izni- 
mno plodno istraživačko područje. Analogijom prema kulturalnim, otočnim ili pak rodnim studijima, "prehrambeni studiji” čine se prihvatljivim izborom bez obzira na to što se jasno prepoznaje jezično porijeklo. Budući da se u zadnjih dvadesetak godina proučavanje prehrane pokazuje vrlo zanimljivim, ali i istraživački kompleksnim područjem u čijoj se samoj srži nalazi zahtjev za multidisciplinarnim i/ili interdisciplinarnim sagledavanjem, pojam prehrambenih studija labavo obuhvaća metodološki i teorijski različita istraživanja prehrane. Prije korišteni pojmovi antropologije prehrane ili kulturne antropologije prehrane čine nam se nedovoljno rastezljivim i suviše lako oborivim u raspravi o temama, metodologijama, teorijama i dosezima suvremenih istraživanja prehrane. Ponajviše zbog toga što se u domaćoj etnološkoj istraživačkoj tradiciji pitanje istraživanja prehrane uopće ne postavlja kao primarno. Prehrambene prakse i kultura prehrane kao istraživačka se tema pojavljuju tek unazad tridesetak godina, a zadnjih petnaestak se afirmiraju kao zasebno područje.

Istraživanja prehrambenih tema prije nastanka multidisciplinarnih prehrambenih studija ${ }^{1}$ odvijala su se unutar sociologije, etnologije i antropologije, kao i povijesti te ekonomije. No prehrana je bila tek sredstvo kojim su se mogla sagledati različita područja, a ne samostalan predmet istraživanja. U ovome će se radu pokušati dati pregled značajnih pristupa istraživanju prehrane koja su prethodila nastanku istraživačke platforme "prehrambenih studija”, pokušat će se skicirati razvoj istraživanja u sociologiji, kulturnoj antropologiji i etnologiji i povijesti te tako pružiti uvid u najznačajnije teorijske i epistemiološke značajke današnjeg širokog pojma prehrambenih studija. Također, u radu se očituje namjera da se što jasnije prikaže razvoj istraživačkog interesa međusobno srodnih disciplina, čija se istraživanja danas objedinjuju pod nazivom prehrambenih studija (bez obzira na disciplinarno ishodište istraživača) te se u njemu nalaze, prema mišljenju i izboru autorica, relevantni znanstvenici i teoretičari čiji su pristupi međusobno isprepleteni ili se metodološki i teorijski nadopunjuju, a ne kronološki nasljeduju. Na početku rada objašnjava se razvoj istraživačkog impulsa u radovima sociologa, zatim se nastavlja s razvojem kulturnoantropoloških istraživanja kroz funkcionalističku i strukturalističku perspektivu. Nadalje, u radu se daje pregled ranih radova u europskoj etnološkoj tradiciji koji su utjecali na bavljenje prehranom u Hrvatskoj te slijedi pregled povijesnih istraživanja prehrane da bi se na kraju rada objasnio razvoj prehrambenih studija u širem kontekstu. Temeljni izvori na kojima se zasniva ovaj pregled istraživanja prehrane su knjiga Prehrana i kultura - sociologija prehrane Stephana Mennella, Anne

\footnotetext{
${ }^{1}$ Prema McIntosh i Nestle (2010), prehrambene studije u širem kontekstu možemo razumijevati kao intelektualni pokret koji se, u okviru društvenih i humanističkih znanosti, približava kulturalnim studijima, prvenstveno u multidisciplinarnom i interdisciplinarnom promišljanju odnosa hrane i ljudi $u$ društvenom i kulturnom smislu.
} 
Murcott i Aneke H. van Oterloo te članak Petera Scholliersa "Twenty five years of studying un Phénomène social total; food writing on Europe in the $19^{\text {th }}$ and $20^{\text {th }}$ century", koji je prethodio knjizi istog autora Writing Food History, a Global Perspective što ju je objavio s Kyri W. Claflin. Izbor tih djela nije nasumičan, već odabran ne bi li se ocrtali početni impulsi istraživanja, koje donose Mennell, Murcott i van Oterloo, te iznio pokušaj sagledavanja razvoja "povijesti prehrane" s odmakom od dvadesetak godina što ga donosi Peter Scholliers. Ovaj rad u skladu je s razmišljanjima o razvoju istraživanja prehrane iznesenim u recentnoj literaturi, ${ }^{2}$ koja ipak ne obiluje pregledima istraživanja prehrane zadnjih dvadesetak godina.

\section{RAZVOJ ISTRAŽIVAČKOG IMPULSA U SOCIOLOGIJI}

Gotovo potpun izostanak tema vezanih uz prehranu u djelima klasičnih sociologa Mennell, Murcott i van Oterloo (1998) objašnjavaju dvama osnovnim razlozima. S jedne strane banalnost, odnosno biološka nužnost uzimanja hrane, a s druge njezina samorazumljivost i univerzalnost. Uz to, legitimaciji istraživanja prehrane priječilo je i vrednovanje javne sfere političkog i gospodarskog kao jedinih dostojnih tema ozbiljne znanosti. U radovima klasika sociološke literature Marxa, Webera i Durkheima hrana je tek sporedan interes. Kada se teme prehrane i spominju u radovima one su tek pokazatelj drugih društvenih fenomena, primjerice indikator društvenog statusa ili dio proizvodnog procesa. Raspon tema u kojima se hrana posredno pojavljuje ide od društvene nejednakosti, npr. Engels Položaj radničke klase u Engleskoj (1952 [1845]) do Spencerovih istraživanja restriktivnih zakona kojima se regulira korištenje i raspodjela hrane, klasifikacije svetog i profanog u odnosu na rodnu pripadnost (Durkheim 2008 [1912]) ili pak njezine ritualne i ceremonijalne društvene funkcije. Među najznačajnijim, i danas najcitiranijim djelima svakako je Veblenova Teorija dokoličarske klase (2008 [1899]) koja promatra konzumaciju hrane i pića kao sredstva prestižne potrošnje, ali i kao sredstvo društvene diferencijacije što se osobito ističe u ceremonijalnim prigodama, čime Veblen anticipira istraživanja hrane kao sredstva reprezentacije društvenih grupa i klasa. Povezujući upravo slobodno vrijeme, uz obrazovanje, sa specifičnim načinima potrošnje, Veblenov ukus društvenih skupina prethodi Bourdieovoj teoriji distinkcije. Slično prehranu shvaća i Georg Simmel u svom članku Sociologija obroka (1910), koji naglašava društveni značaj hrane od pradavnih vremena, prepoznajući i ističući zajedničko blagovanje i s njime povezane sustave propisa i zabrana. Simmel će anticipirati ulogu estetske stilizacije hrane i stvaranje normi,

${ }^{2}$ Više vidi u Murcott Warren i Jackson (2013). 
vidljivih u obrascima ponašanja za stolom, koje će kasnije razraditi Norbert Elias u svome Civilizacijskom procesu (1996 [1939]). Iako se Elias ne bavi samom hranom, u smislu sadržaja prehrambenih praksi i izbora ili normi, nego opisuje razvoj ponašanja viših slojeva u Europi od srednjeg vijeka, analizirajući rasprave i priručnike o dobrom vladanju, njegova studija o ponašanju za stolom također je iznimno značajna zbog naglašavanja reprezentacijske uloge hrane. Pedesete godine 20. stoljeća ne donose veći interes sociologa za prehranu, ali se povremeno prepoznaje njezina simbolička funkcija. Tako Riesman (Usamljena gomila 1965 [1950]) opisuje ulogu hrane kao sredstva društvenog nadmetanja, odnosno njezinu povezanost s društvenom statusom. Takvo shvaćanje prehrane bit će ishodište rada Pierra Bourdieua, jednog od danas najutjecajnijih sociologa u istraživanjima prehrane. U svojoj knjizi Distinkcija: društvena kritika suđenja (2011 [1979]) Bourdieu se ne bavi samo prehranom već istražuje i odjeću, namještaj, vizualne umjetnosti, kinematografiju - odnosno sve oblike ponašanja koja se pripisuju individualnom ukusu. Bourdieu u središte svoje socijalne teorije stavlja distinkciju, naslanjajući se pritom na Veblena, međutim u okviru teorije reprodukcije društvenih klasa. Njegov koncept ukusa, usko povezan s klasom, odnosno pitanjem odnosa kulturnog i ekonomskog kapitala, omogućuje razlikovanje različitih sustava prehrambenih preferenci (popularni, luksuzni....). Ukus se tako nameće kao utjelovljenje kulture klase koju istodobno oblikuje. Radi se, dakle, o principu klasifikacije koji upravlja "odabirom i preinakom svega što tijelo unosi i probavlja te asimilira, kako fiziološki tako i psihološki" ${ }^{3}$ (Bourdieu 2005: 5).

Bourdieu razlikuje dva osnovna ukusa - luksuzan i nužan, što ih povezuje sa složenošću društvenih klasa. Tako će pojedinci niže klase biti određeni svojim vulgarnim ukusom, a oni s više kulturnog kapitala rafiniranim, luksuznim i slobodnim ukusom. Bourdieu istražuje bitku za kulturnu otmjenost kojom objašnjava genetiku društvenog ukusa, odnosno bitke za simbole društvene distinkcije između društvenih grupa. U svome tekstu "Taste of luxury, taste of necessity" (2005) promatra ukuse ukorijenjene u društvene odnose, razumijevajući ukus kao "tipično buržoaski, budući da pretpostavlja apsolutnu slobodu izbora” (Bourdieu 2005: 73). Prehrambeni izbori i ukus shvaćeni su kao ključni faktori u razumijevanju ponašanja i dinamike različitih društvenih grupa. Ukusu slobode, odnosno ukusu luksuza suprotstavljen je ukus nužde, a u pozadini se ne nalaze samo klasne preferencije, već i ideja što je svaka klasa posjeduje o tijelu i utjecaju hrane. Bourdieu zaključuje: "Ukus je amor fati, izbor sudbine, no prisilan izbor, proizašao iz životnih uvjeta koji svaku alternativu odbacuju kao puko sanjarenje, ne ostavljajući mjesta ni za što, osim ukusa nužde" (Bourdieu 2005: 74).

\footnotetext{
${ }^{3}$ Svi prijevodi s engleskog su autoričini.
} 
Poput Mennella, francuski sociolog Claude Fischler (1990) Bourdieu zamjera nedinamičnost, odnosno stav da je klasna pokretljivost gotovo nemoguća. Jednako kao i Goody (1982), Fischler odbacuje biološki faktor iz objašnjenja društvenih obrazaca. Razlikujući pojam mangeur éternela i mangeur modernea Fischler dolazi do paradoksa sveždera, osobitosti ljudske vrste koja se prehranjuje različitim vrstama hrane, ali joj ta sposobnost uz veliku mogućnost prilagodbe sa sobom donosi i tjeskobu, budući da je svaka nepoznata hrana i potencijalno opasna. Fischler upravo u tom procjepu između neofilije i neofobije vidi početni impuls razvitka mnogih kulinarskih sustava (Mennell, Murcott i van Oterloo 1998: 20).

\section{KULTURNOANTROPOLOŠKA ISTRAŽIVANJA - KULTURA PREHRANE KAO PREDMET ISTRAŽIVANJA}

Za osamostaljivanje prehrane kao istraživačke teme, danas prisutne u gotovo svim znanstvenim poljima, presudni su bili doprinosi socijalne antropologije i etnologije. Tu se osobito ističe britanska antropološka škola i radovi Audrey Richards, Alfreda Radcliffe-Browna i Edwarda Ewans-Pritcharda. Funkcionalistički antropolozi u svojim istraživanjima (npr. Richards u istraživanjima južnoafričkih plemena, 1932, 1937, 1939) obuhvaćaju cijeli prehrambeni lanac: proizvodnju, pripremu i konzumaciju te pozicioniraju hranu u psihološki kontekst, povezujući je sa životnim ciklusom i strukturom te dinamikom društvenih grupa. Među prvim značajnijim antropološkim radovima ističe se studija o gladi, koja će ostati bitno antropološkom temom sve do naših dana, Hunger and Work in savage Tribe: A Functional Study of Nutrition among the Southern Bantu Audrey Richards iz 1932. Istraživanje Richardsove prati proizvodnju, pripremu i konzumaciju hrane, koju povezuje sa životnim ciklusom i društvenom strukturom. Prebacujući fokus istraživanja s pitanja proizvodnje na oblike potrošnje, funkcionalistički pristup prije svega osvjetljava "kako su načini postupanja s hranom izražavali ili simbolizirali model društvenih odnosa" (Mennell, Murcott i van Oterloo 1998: 13). Tako se pokazuje da je pripremanje i uzimanje hrane u izravnoj vezi s očuvanjem društvenih struktura, što se osobito ističe u rodnoj podjeli poslova vezanih uz pripremu hrane. Mennell, Murcott i van Oterloo ističu da je takav pristup danas uglavnom predmet kritike zbog svoje imanentne teleologije, cirkularnosti i atemporalnosti (1998: 149), no ne može mu se zanijekati ukazivanje na važan dio problematike kojim se prehrambeni studiji danas bave.

Nezaobilazan doprinos prehrambenim studijima, kako ih danas razumijemo, dali su strukturalistički radovi Claudea Lévi-Straussa, Mary Douglas, Rolanda Barthesa te dijelom Pierrea Bourdieua i Claudea Fishlera. Kulturološki obrat koji je nastupio u istraživanju prehrane bio je značajan ne samo 
za sociološka istraživanja, nego i za povijesne analize koje se počinju okretati kulturnoj teoriji. Doprinos tog teorijskog pristupa svakako je bilo shvaćanje društvene konstruiranosti ukusa, kao i izostanak biološkog redukcionizma i implicitnog etnocentrizma. Radovi strukturalista, za razliku od utilitarizma funkcionalista i nutricionista, isticali su estetske aspekte jela, odnosno predmet njihova istraživanja nije bila hrana nego kuhinja (cuisine) (Fischler 1990; Mennell, Murcott i van Oterloo 1998). Iako su se interpretativne mogućnosti strukturalističkog pristupa pokazale ograničenima te im se zamjerala statičnost, odnosno eksplikativna nemogućnost sagledavanja razvoja i promjene ukusa kroz vrijeme (Mennell 1985: 7), utjecaj radova Lévi-Straussa i Mary Douglas kao i semiotičara Rolanda Barthesa danas je neosporan. Znameniti i kritizirani Lévi-Straussov kulinarski trokut, koji na svojim krajnjim točkama spaja sirovo, kuhano i pokvareno, uspostavljajući pritom opoziciju prirode i kulture u ljudskom djelovanju, pokušaj je da se "najlakšim mogućim putem" (Mennell, Murcott i van Oterloo 1998: 16) dođe do univerzalnih modela kulture. Kuhinja za Lévi-Straussa predstavlja jezik kojim društvo nesvjesno otkriva, odnosno prevodi svoje strukture i u njima skrivene suprotnosti. Na temelju teorija strukturalne lingvistike, uspoređujući francusku i englesku kuhinju, Lévi-Strauss uvodi pojam gustema koji predstavlja konstitutivne jedinice značenja. "Imam dojam da se, poput jezika, kuhinja nekog društva može raščlaniti na sastavne dijelove, koje u ovom slučaju možemo nazvati 'gustemi', a koji se mogu organizirati u određene strukture suprotnosti i suodnosa" (Lévi-Strauss 1977: 96).

Nakon gustema Lévi-Strauss se okreće analizi osnovnih kuharskih postupaka upisujući u trokut dimljenje, kuhanje i pečenje, uključujući pritom djelovanje zraka i vode u pripremi hrane. Te analize prehrane $u$ velikoj su mjeri smatrane tek intelektualnom vježbom, ponavljanjem stereotipa (u analizi francuske i engleske kuhinje) sofisticiranim jezikom te zapostavljanjem temeljne opozicije između nutritivne i estetske funkcije hrane (Goody 1982; Mennell 1985; Fischler 1990). Za razliku od Lévi-Straussa, radovi Mary Douglas znatnije su utjecali na sociologiju prehrane. Odustavši od univerzalnosti koja bi bila kodirana u jeziku prehrane, Mary Douglas naglasak istraživanja postavlja na utjecaj kulture koji oblikuje individualne preferencije. Značajan tekst Mary Douglas Deciphering a Meal iz 1975. ne donosi analizu obroka, već sijedova jela i određenih svečanih jelovnika te prehranu shvaća kao sredstvo dekodiranja društvenih događaja (nadogradnja jelovnika s obzirom na prigodu, primjer strukture božićnog ili nedjeljnog ručka u odnosu prema onome svakodnevnom). Struktura obroka služi kao barijera prema vanjskom svijetu, a hijerarhija obroka u tjednom ili godišnjem ciklusu ponavlja se nadgradnjom na osnovne elemente (meso i dvije vrste povrća). "Kategorije hrane dekodiraju društvene događaje: [...] one odražavaju hijerarhiju, uklju- 
čenost ili isključenost, ograničenja i načine njihova prekoračivanja" (Douglas 1975: 260). Utjecaj Mary Douglas bio je ključan s obzirom na razvoj simboličke perspektive u istraživanjima kulture prehrane i u etnologiji i kulturnoj antropologiji zanemarene kulture pijenja (Douglas 1975, 1987). Prehrana se razumijeva kao medij koji u sebi generira razna značenja, i ona privatna i ona javna, a navike i običaji povezani s hranom i pićem instrumenti su pomoću kojih se mogu promatrati obrasci vlastite kulture i pripadnosti određenom kulturnom krugu, medij kojim društva komuniciraju svoje strukture, vrijednosti i obrasce ponašanja.

Utjecaju strukturalista na istraživanja prehrane svakako je pridonio Roland Barthes, prije svega svojim esejom Toward a psychosociology of contemporary food consumption (2008 [1961]), ali i nekim kratkim esejima o hrani i piću sakupljenim u knjizi Mitologije (2009 [1957]). Posve u duhu strukturalističke teorije, Barthesov interes za prehranu vodi se potragom za kodovima ili gramatikom koja bi izražavala preferencije i vrednovanja pojedine hrane. Prehrana je tako shvaćena kao komunikacijski sustav čiju sintaksu čine jelovnici, a stil osobiti modeli prehrane i prehrambeni izbori. Sustav prehrane za Barthesa odražava: "snove, ukuse, izbore i vrijednosti [...] ne vidimo vlastitu hranu ili, još gore, pretpostavljamo da je ona nebitna [...] prehrana podrazumijeva i trivijalnost i krivnju" (Barthes 2008: 28). Neki od znakova koje je Barthes analizirao bili su vino i mlijeko, biftek i krumpirići, ornamentalna kuhinja, kava... Barthesov interes privlačila je prvenstveno semiotika reklamiranja hrane te recepti (objavljeni u kuharicama ili ženskim časopisima). U tekstu u kojem analizira okuse gorkog i slatkog (koji u američkoj kulturi zauzima prvenstvo među okusima) postavlja osnovnu razliku između dviju kulinarskih tradicija, francuske i američke. Analizirajući francuski kulinarski diskurs u oglasima koji ističu seksualnost i nostalgični osjećaj prošlosti, Barthes prošlost ne uzima kao objektivan zapis, nego kao platformu za ispitivanje potencijalnih značenja (spomenimo tek tekst o kavi koji prati mijenjanje značenja od stimulansa koji pomaže radu do pića koje označava stanku, predah u danu kada se vrijeme na čas usporava) (Barthes 2008: 34). Interpretativni okvir Barthesovih kratkih eseja nacionalna je kuhinja što mu omogućuje shvaćanje komemorativne funkcije hrane. Tako jedenje određenog jela omogućuje sudjelovanje u nacionalnoj prošlosti (Barthes 2008: 32). Tekst o ornamentalnom kuhanju, odnosno analiza vizualnog sadržaja kulinarske rubrike u časopisu Elle, u kojem Barthes britko otkriva društvenu funkciju prehrane i kulinarsku pomodnost, vjerojatno je prvi u kojem se hrana povezuje s pornografijom, te anticipira nastanak današnjeg pojma gastroporna, koji ističe simulakrumske odlike medijskog kulinarstva što balansirajući između utilitarnosti i zabave izabire ovo potonje (Rousseau 2012; Cockburn 1977). 


\section{MATERIJALISTIČKI ODGOVOR NA RADOVE STRUKTURALISTA}

Odgovor na strukturalistička istraživanja prehrane, kao kritiku onoga što su neki autori (Goody, Mennell, Murcott) smatrali vježbom iz metafizičkog teoretiziranja, ali i strukturalističku nemogućnost da objasni dinamičnu prirodu sustava ljudske prehrane, stigao je s radovima Jacka Goodya Cooking, Cuisine and Class (1982), Stephena Mennella All Manners of Food (1985) i Sidneya Mintza Sweetness and Power (1985). ${ }^{4}$ Ta se istraživanja mogu shvatiti kao odgovor materijalista na strukturalizam, iako su neki od prijašnjih pristupa, poput Lévi-Straussova povezivanja kuhanja i kulture u cijelosti bila presudna za smjer daljnjih istraživanja. Kuhanje je, naime, tako shvaćeno kao ključan faktor u razvoju ljudskih intelektualnih sposobnosti i društvenog uređenja, a uloga hrane svakako nadilazi puko održavanje života. Ona istodobno predstavlja i izvor bogatstva i sredstvo društvenog uključivanja i isključivanja, normativni faktor društvenog uređenja. Među radovima developmentalista ističe se knjiga Marvina Harrisa Good to Eat: Riddles of Food and Culture (1986) u kojoj je kao kontrapunkt strukturalističkim radovima naglašen arbitraran karakter značenja hrane i njezine objektivne nutritivne vrijednosti. Harris istražuje obrasce prehrambenih preferencija i zabrana na primjerima svetih krava u Indiji, židovske i muslimanske zabrane konzumiranja svinjetine, odbacivanje mlijeka iz prehrane u Kini ili dilemu o jestivosti kućnih ljubimaca (temi kojoj će kasnije Fiddes (2002) posvetiti velik dio svoje knjige Meso: prirodni simbol). Harrisova knjiga pokušava razotkriti korijene određenih prehrambenih izbora karakterističnih za pojedina društva i kulture, a pritom zaključuje da će "jednom postignuti rezultati [prehrambenih izbora] trajati snagom simbolike i unutarnjih oprečnosti" (Mennell, Murcott i van Oterloo 1998: 23). Drugi su autori manje interesa posvetili klasičnom antropološkom pitanju preferenci i zabrana hrane, okrenuvši se istraživanju razvitka kuhinje (cuisine) kao simboličkog i kulturnog kapitala pojedinog društva ili, pak, istraživanju pojedinih namirnica. Radovi trojice autora, Mennella, Mintza i Goodya, danas se smatraju kanonskim tekstovima prehrambenih studija. Knjiga Jacka Goodya Cooking, Cuisine and Class (1982) bavi se pitanjem zašto se u određenim društvima razvijaju dvije oprečne kuhinje - haute cuisine i jednostavna pučka kuhinja. Veza između društvene i političke složenosti i elaboriranosti kulinarskog sustava nije, smatra on, jednoznačna, odnosno razvitak različitih kulinarskih sustava unutar nekog društva ne ovisi o složenosti društvenog/političkog uređenja. Do toga zaključka Goody dolazi istražujući prehranu dvaju plemena iz Sjeverne Gane. Diferencijaciju kuhinje Goody promatra i kroz komparativno istraživanje kuhinja drevnog Egipta,

${ }^{4}$ Te autore Mennell, Murcott i van Oterloo (1998) nazivaju developmentalistima budući da prehranu opisuju kao dinamičan proces, inzistirajući na istraživanju razvoja pojedinih prehrambenih sustava. 
Indije i Kine, kao i europskih kuhinja u razdoblju razvitka industrijalizirane prehrane. Proučavajući sustave stratifikacije Goody također proučava utjecaj pismenosti i njezinu ulogu u utvrđivanju granica između viših i nižih društvenih slojeva. Uloga pismenosti u kulinarskoj kulturi je dvojaka; pristup pisanim tekstovima ograničen je te je u tom smislu ona restriktivna, dok su istodobno kulinarski priručnici i kuharice, omogućujući uvid u modele ponašanja i prakse svojstvene višim klasama, uputa onima koji aspiriraju prema višem društvenom statusu. Nepostojanje visoke kuhinje u pojedinim kulturama Goody objašnjava organizacijom privatnog prostora doma i rodbinskih veza. Podjela poslova vezanih uz pripremu hrane indikativna je, tako se visoka kuhinja razvija u društvima gdje te poslove obavljaju profesionalni kuhari i sluge. Razliku između dvorske i domaće kuhinje, pri čemu se prvoj dodjeljuju epiteti visoke i elaborirane, ističe i Stephan Mennell u svojoj knjizi All Manners of Food (1985). Razvoj kulinarske kulture u Francuskoj i Velikoj Britaniji od srednjeg vijeka u Mennellovoj studiji promatran je kroz opreku visoke i niske (profesionalne i privatne) kuhinje, kulinarskih tekstova i suodnosa dvaju kulinarskih sustava što, iako bliski, svoju prepoznatljivost stvaraju u odnosu prema drugome. Mennellovo teorijsko ishodište je sociologija procesa, kako je shvaća Elias u svojim djelima O procesu civilizacije (1996 [1939]) i The Court Society (1983 [1969]). Izražavanje emocija, ponašanje, te prije svega za Mennella bitno, ukus i stil života odražavaju društvene, političke i ekonomske promjene. Promjene u društvenoj strukturi oblikuju promjene u strukturi prehrane, vrednovanju pojedine vrste hrane te uvjetuju nastanak specifičnih nacionalnih kuhinja. Ukus je zbog toga društveno i kulturno uvjetovan. Stol tako postaje metafora društvenog uređenja, od srednjovjekovnog smjenjivanja posta i gozbi, razdoblja gladi i obilja do uspostavljanja ravnoteže između vanjske prisile i unutarnje kontrole. Dok je Eliasa zanimala samokontrola, izražena promjenama u manirima, ${ }^{5}$ Mennellov je interes mnogo širi budući da komparativno promatra dvije, zapravo bliske, kulinarske kulture u cijelosti. Inovacije u uzgoju i dostupnosti hrane rezultirale su odbacivanjem srednjovjekovne prenatrpane trpeze za kojom je gargantuanski apetit bio jedan od izraza položaja i moći. Nekoć veliko i moćno tijelo zamijenjeno je idealom vitkosti (koji osobito pogađa žene) ${ }^{6}$ Ideal više

\footnotetext{
${ }^{5}$ Jedan od primjera razvoja manira koje je Elias iščitavao bio je brisanje nosa. Tako su srednjovjekovna društva pravila o čišćenju nosa vezala isključivo uz ponašanje za stolom, kada je nos valjalo brisati lijevom rukom, dok se desnom uzimala hrana. U renesansi pitanje rupčića postaje stvar prestiža; dva stoljeća kasnije, iako korištenje rupčića postaje općeprihvaćeno, navada korištenja prstiju ili rukava za brisanje nosa nije još sasvim nestala, pa gledana odozgo postaje primjer vulgarnosti (Elias 1996: 197). Razvoj ponašanja za stolom, osobito korištenja pribora za jelo, pokazuje razvoj samoprisile kojim vlada društveno prihvaćeni "standard mučnine" (isto: 175).

${ }^{6}$ Punašno žensko tijelo smatralo se idealom ljepote još ne tako davno. Pišući o debljini i mršavosti, Brillat Savarin zaključuje: "Mršavost nije velika neprilika za muškarce; od nje im se ne smanjuje snaga, i mnogo su okretniji [...] Ali strašna je to nesreća za žene, jer za njih je ljepota više nego život, a ljepota se sastoji naročito u oblini oblika i ljupkoj savijenosti crta [...]" (Brillat Savarin 1998: 166 [1825]).
} 
nije potkoženost nego produhovljena vitkost. ${ }^{7}$ Dvije suprotstavljene kuhinje, barem u danas općeprihvaćenom antagonizmu između stereotipa o visokoj francuskoj i nejestivoj engleskoj kuhinji, ${ }^{8}$ Mennell pomiruje u paralelnom razvoju njihovih prehrambenih kultura. Kuhinja se kod Mennella promatra kroz izmjenu moda, stilova i promjena kulinarskog diskursa.

Pristup Sidneya Mintza u njegovoj kultnoj knjizi Sweetness and Power (1985) nešto je drukčiji. Mintzovo ishodište kritika je strukturalizma budući da se značenje ne može samo dešifrirati, nego ga treba razumijevati kao posljedicu aktivnosti: "ne zapitati se kako je značenje usađeno u ponašanje [...] znači ponovno ignorirati povijest" (1985: 14). Mintzova studija o šećeru jest povijest europskih plantaža šećerne trske u Zapadnoj Indiji od 16. stoljeća, koja odražava društvene i ekonomske sustave. Početkom 18. stoljeća šećer je prestao biti rijetka i otmjena namirnica te je postao prva luksuzna masovno proizvedena namirnica dostupna svim društvenim slojevima. Povećanje proizvodnje i konzumacije šećera nemoguće je promatrati izvan političkih, ekonomskih i prehrambenih potreba, koji potom oblikuju njegovo značenje.

\section{ETNOLOŠKA ISTRAŽIVANJA PREHRANE}

Doprinosom etnologije, koju Mennell, Murcott i van Oterloo smatraju donekle egzotičnom znanošću što se razvila u Njemačkoj, Istočnoj Europi i Skandinaviji, uglavnom se smatra opisivanje tradicionalnih elemenata narodne kulture: praksi, običaja i materijalnih predmeta (1998: 35). Etnološka istraživanja spomenuti autori smještaju između povijesti i antropologije. Uloga etnologije, prema Scholliersu (2007), velika je budući da njezina metodologija omogućuje pogled iznutra te etnolozima pripisuje maštovitost u izboru izvora. Do sedamdesetih i osamdesetih godina hrana je postupno postala popularna tema istraživanja, a u svrhu boljeg protoka ideja i informacija utemeljene su mnoge međunarodne organizacije kao što su The International Comitee for the Anthropology of Food and Food Habits (1968), Ethnological Food Research Group (1970), International Commission on the Anthopology of Food (1977), International Commision for Ethnological Food Research (1970). Zbornici s kongresa tih asocijacija sadrže pregled glavnih preokupacija onodobnih etnoloških i antropoloških istraživanja. ${ }^{9}$ Među

\footnotetext{
${ }^{7}$ Tema vitkosti danas je doista aktualnija od problema gladi, osobito u američkoj znanstvenoj produkciji. Više o istraživanjima problema vitkosti i s njim vezanih poremećaja u prehrani u Mennell, Murcott i Otterloo (1998), Braziel i LeBesco (2001).

${ }^{8} \mathrm{U}$ bitku protiv poznatog stereotipa o nejestivoj engleskoj kuhinji ustao je i George Orwell u svom eseju In Defence of English Cooking (1945).

${ }^{9}$ Analizu sadržaja zbornika ICREF-a donosi Peter Scholliers u svome tekstu Twenty Five Years of Studying un Phénomène Social Total; Food Writing on Europe in the $19^{\text {th }}$ and 20 $0^{\text {th }}$ Century (2007). Više o istoj temi vidi u Scholliers, Claflin. 2012. Writing Food History, a Global Perspective. London: Bloomsbury.
} 
temama, koje su se unutar sociologije i povijesti istraživale uglavnom kvantitativnom metodom, pojavljuju se interesi kojima je doseg izvan uobičajenih socioekonomskih istraživanja, a tiču se komunikacijske, reprezentacijske i hedonističke funkcije hrane. Prateći pregled etnoloških istraživanja prehrane prema Mennellu, Murcott i van Oterloo, potrebno je spomenuti knjigu Günthera Wiegelmanna Alltags und Festspeisen: Wandel und gegenwärtige Stellung (2006 [1967]), koja je, iako prva među etnološkim studijama hrane, značajna još i danas. Wiegelmann pokušava pratiti promjene u obrascima njemačke prehrane tijekom 18. i 19. stoljeća. U središtu interesa nalaze se inovacije koje su generirale veće promjene prehrambenih modela, među najznačajnijim namirnicama svakako se ističe krumpir. Još u prvoj polovici 18. stoljeća krumpir se smatrao sirotinjskom hranom, da bi se do kraja 19. stoljeća udobno smjestio na građanske trpeze postavši jedan od glavnih izvora škroba. Put kave, koji je također trajao stotinjak godina, bio je drukčiji. Kava je napredovala odozgo, do početka 20. stoljeća prestala se smatrati luksuznom namirnicom i postala jedan od temelja radničke prehrane (uz već spomenuti krumpir, kruh i margarin). ${ }^{10}$ Otprilike u isto vrijeme kada i šećer, kava se prestala smatrati egzotičnom. Put namirnice od jedne do druge društvene grupe ukazuje na goleme društvene, političke i kulturne promjene kraja 19. i početka 20 stoljeća.

Sedamdesetih godina uslijedili su još mnogi zanimljivi etnološki radovi. Spomenimo Margaret L. Arnott Gastronomy: The Anthropology of Food and Habits (1975), koja se bavila temama u rasponu od povijesnog razvoja poljoprivrede u prahistoriji, porijekla uzgoja kukuruza ili pravljenja vina, kuhinjske opreme u Maineu u 18. stoljeću, do narodnih vjerovanja vezanih uz, primjerice, kruh. Zbornik Alexandera Fentona i Trevora M. Owena Food in Perspective: Proceedings of The Third International Conference on Ethnological Food Research (1981) sadrži zbirku tekstova bez čvrstog teorijskog ili metodološkog okvira, a nalaze se tu tekstovi o krušnim mrvicama, TV večerama, brzoj hrani, tradicijskim jelima od brašna u Bugarskoj... Osamdesetih godina počinje značajnije i sustavnije istraživanje prehrane. Ističu se studije o rasprostranjenosti konzumacije bijelog i crnog kruha u Nizozemskoj od srednjeg vijeka (Voskuil 1983), regionalnim varijantama konzerviranja hrane u Nizozemskoj u prvoj polovici 20. stoljeća (Jobse-van Putten 1989) kao i radovi koji su se bavili periodizacijom, odnosno markiranjem osnovnih prijelomnih točaka povijesti prehrane (Kisbán 1986; Teuteberg 1986). Zbornici kongresa ICEFR-a održani devedesetih i dvijetisućitih govore o pomicanju interesa s hrane prema prehrambenim sustavima, pitanju ukusa, utjecaju

${ }^{10}$ Opisane promjene podudaraju se s rezultatima istraživanja u Engleskoj i Nizozemskoj (Burnett 1989; van Oterloo 1990). 
migracija i turizma u stvaranju etničkih kuhinja i promjenama prehrambenih obrazaca.

Etnološka istraživanja kulture prehrane u Hrvatskoj odvijala su se unutar različitih pristupa i analitičkih dosega: od sakupljanja podataka o tradicijskoj seoskoj prehrani, kulturnopovijesnih potraga za porijeklom pojedinih elemenata tradicijske prehrane, istraživanja regionalnih posebnosti do suvremenih kulturnoantropoloških pristupa koji kulturu prehrane sagledavaju unutar cjelovitosti društvenog konteksta (Belaj 2013: 165). Interes za istraživanjem prehrane u hrvatskoj etnološkoj znanosti uvijek je slijedio dominantnu paradigmu hrvatske etnološke misli. Kronološki najranije, u začecima oblikovanja same etnologije kao znanosti u Hrvatskoj, podatke o prehrani stanovništva možemo pronaći u Zbornicima za narodni život i običaje te monografijama nastalim prema uputi Antuna Radića iz Osnove za sabiranje $i$ proučavanje građe o narodnom životu. ${ }^{11}$ Nadalje, u Etnološkom atlasu Jugoslavije što ga je osmislio Branimir Bratanić, prehrambena je tematika obrađena u drugome svesku (1965) s otprilike deset pitanja. Hrvatski etnolog Milovan Gavazzi temi prehrane posvetio je nekoliko radova i studija. U članku "Seoska prehrana u Jugoslaviji - Izvori i istraživanja” (1978a) Gavazzi smatra da se cjelokupni materijal o prehrani s bilo kojeg područja, naroda ili kulture može podijeliti, promatrati i prosuđivati s različitih stajališta:

1. kulturnogeografski, tj. regionalno raščlanjeno za određeni prostor;

2. kulturnopovijesno, s obzirom na povijesnu sudbinu pojedinih vrsta hrane unutar određenih okvira, njihova podrijetla odnosno starosti;

3. iz perspektive društvene povezanosti i uloge pojedinih vrsta jela i pića;

4. pregledno grupiranje prema vrstama hrane i pića (1978a: 108).

Također, smatra on, prvi, treći i četvrti način promatranja imaju značaj sistematizacije i orijentacije, a drugi se može označiti kao etnološki, odnosno poredbeno kulturološki. Primjer tome, kako ga Gavazzi naziva, poredbenokulturološkom načinu istraživanja prehrane je i njegova studija "Oko podrijetla jednog blagdanskog peciva južnih Slavena” (1978b).

Do osamdesetih godina u većini etnografskih istraživanja starija se građa koristila kao temelj za istraživanje i komparaciju sa stanjem zatečenim na terenu. Na tom tragu istraživali su se tradicijski elementi u suvremenom kontekstu ili bi se iscrpno opisivala prehrana određene regije. Može se reći da su se istraživanja prehrane uglavnom oslanjala na povijesne izvore te ograničavala na kulturnopovijesne analize podrijetla kulturnih elemenata

${ }^{11}$ Hrvatska akademija znanosti i umjetnosti osnovala je 1888. godine Odbor za narodni život i običaje u okviru kojeg je 1897. počela izlaziti publikacija Zbornik za narodni život i običaje. Osnivanjem tog Odbora u Hrvatskoj je započeo sustavan i organiziran rad na prikupljanju etnografske i folklorističke građe o narodnom životu, običajima i tradicijskoj kulturi. Tada su Akademiji počeli stizati mnogi rukopisi iz pojedinih krajeva Hrvatske u kojima su obrazovani i školovani ljudi kao npr. svećenici, učitelji, veterinari ili općinski bilježnici zapisivali odgovore na pitanja iz Osnove. 
tradicijske prehrane ili na njihovu geografsku rasprostranjenost. Takvo svojevrsno ograničenje odgovaralo je općoj težnji rekonstrukcije prošlosti nacionalne kulture na temelju tragova u suvremenim običajima. Devedesetih se godina postupno premošćuje deskriptivna razina i zadržavanje na dotada uvriježenim i zadanim istraživačkim okvirima te se istraživanje prehrambenih praksi smješta u okrilje šireg pojma etnologije svakodnevnice, koja je ušla u polje hrvatskog etnološkog interesa radom etnologinje Dunje Rihtman-Auguštin. ${ }^{12}$ Suvremena istraživanja prehrambenih praksi uključuju uvođenje hijerarhijskih, rodnih i regionalnih razlika, kao i simboličku i nutritivnu ulogu hrane u društvenom kontekstu i suvereno odgovaraju izazovima društvene klime i svakodnevnice. Nives Rittig-Beljak istraživala je kulturu prehrane specifičnih povijesnih razdoblja, primjerice baroka (2005), te se također bavila prehranom u okviru ratne etnografije (1996, 2000). Osim toga, zajedno s etnologinjom Mirjanom Randić iz Etnografskog muzeja u Zagrebu postavila je zanimljivu izložbu "Svijet hrane u Hrvatskoj" (2006). Popratni katalog sadržajan je i opsežan pregled tradicijske prehrane i suvremene kulture prehrane s kritičkim komentarom tradicijskog u suvremenom kontekstu. Dvojbene percepcije mediteranske prehrane i kao koncepta i kao nutricionističke sintagme okupljene su i predstavljene u zborniku Mediterranean Food: Concepts and Trends (Lysaght i Rittig-Beljak 2006), 15. konferencije Međunarodne grupe za etnološko istraživanje prehrane kojoj je Hrvatska bila domaćin. Istarsku kuhinju u svojim radovima istraživale su Tanja Kocković Zaborski i Ivona Orlić. Kocković Zaborski, ispisujući povijest tek jedne namirnice - tartufa kao simbola istarskog identiteta, ukazala je na mogućnost promišljanja prehrane u zamršenom polju značenja koja joj se pripisuju (2006), a u radovima Ivone Orlić možemo pratiti razvoj i promjene - interpretaciju i reinterpretaciju istarske kuhinje kroz razvoj selektivnih oblika turizma $(2009,2013)$. Deskriptivnu razinu etnografije vinogradarstva kao dijela istraživanja materijalne tradicijske kulture premostila je Melanija Belaj, osvijestivši simboličku i rodnu perspektivu istraživanja kulture obiteljske proizvodnje i konzumacije alkoholnih pića $(2010,2011)$. Iz kulturnoantropološke perspektive, na primjeru novije hrvatske književne produkcije, te koristeći se aparatom književne teorije, Jelena Ivanišević kroz analizu raznolikih kulinarskih i gastronomskih narativa - od poznatih kuharica do suvremenih personaliziranih nostalgičnih kuharica, eseja, memoara i romana - prikazuje i dokazuje uspostavu novog književnog žanra - gastronomske književnosti $(2008,2011,2014)$. Iz svega navedenog razvidno je da, iako mali broj istraživačica djeluje u tom području, njihove analize i interpretacije korespondiraju sa svjetskom produkcijom u polju istraživanja prehrambenih praksi i kulture prehrane općenito.

${ }^{12}$ Više o istraživanju prehrane u Hrvatskoj vidi u Belaj (2013). 


\section{PREHRANA U ISTRAŽIVANJIMA POVJESNIČARA}

Interes povjesničara za prehranu dugo je vremena kočila pretpostavljena banalnost te teme, kao i njezina neraskidiva vezanost uz privatan ženski prostor doma. Kako duhovito primjećuje Fabre: "znati imena kraljeve kopiladi, ali ne i porijeklo pšenice. Tolika je ljudska glupost" (Jean Henry Fabre, prema Belasco 1999: 28). Velike političke i gospodarske teme koje su vladale povijesnom znanošću počele su uzmicati tek 1960-ih. Pojava koncepta povijesti svakodnevice i vie materielle Fernanda Braudela otvorila je put istraživanjima povijesti prehrane. Braudel u svojim Strukturama svakodnevice (1992 [1967]) istražujući povijest određenih namirnica, osobito onih pristiglih iz Novog svijeta, prehrambene obrasce uklapa u svoj koncept procesa dugog trajanja. Prehrambene prakse i vjerovanja, koje odražavaju društvene, ekonomske i političke strukture, pojava su čiji se razvoj nužno mora promatrati u dužim vremenskim razdobljima. Analizirajući osnovne značajke prehrane od 15. do 19. stoljeća, Braudel zaključuje da je prehrambena slika Europe sve do polovice 19. stoljeća odraz pojava čiji se izvori nalaze u srednjem vijeku. Prehrambene revolucije odvijaju se postepeno kroz dugo razdoblje, primjerice postepeno udomaćivanje poljoprivrednih kultura Novog svijeta, prije svega krumpira i kukuruza te njihovo prostorno i društveno širenje, pokazatelji su širih društvenih i ekonomskih prilika. Utjecaj Braudela, kao i povjesničara okupljenih oko časopisa Annales, tu prije svega treba spomenuti Jean-Louisa Flandrina, Massima Montanaria i Brunu Lauriouxa, koji su se okrenuli istraživanjima svakodnevice i materijalne kulture, dao je golem poticaj razvoju povijesti prehrane kao zasebnog polja povijesnih istraživanja. Scholliers (2007) u svojoj analizi povjesničarskih istraživanja prehrane izražava žaljenje što se do devedesetih nisu uzimala u obzir etnološka i antropološka istraživanja, jer se doprinos etnologije smatrao suviše anegdotalnim. Socioekonomska povijest šezdesetih i sedamdesetih godina, prvenstveno analizirana na primjeru istraživanja francuskih povjesničara, uglavnom se može promatrati u trima različitim tematskim okvirima: ekonomsko-poljoprivredna istraživanja (opskrba hranom, glad), kvantitativna rekonstrukcija unosa hrane (unos kalorija, bjelančevina...) i psihosociološka istraživanja jedenja i pijenja (Barlösius 1992: 93, prema Scholliers 2007: 453). Gotovo potpuna prevlast kvantitativnih istraživanja i izostanak teorijskog okvira rezultirali su slabim interpretativnim potencijalom radova nastalih šezdesetih i sedamdesetih godina. Budući da takva istraživanja ne mogu identificirati, istražiti i povezati značenje s istraživanim fenomenom (Bentley 2011: 305), pokazalo se da je njihov utjecaj nužno ograničen. Ranih osamdesetih interes se s pitanja distribucije, cijena i unosa kalorija okreće prema istraživanju kuhanja, ukusa, jela i estetske uloge hrane. Radovi Jean-Louisa Flandrina danas se smatraju velikim iskorakom povjesničara prema etnološkim i 
antropološkim istraživanjima i metodologiji. Flandrin i Montanari (1999) ističu da je upravo razdoblje početka osamdesetih bilo prekretnica prema istraživanju kulture prehrane te da tema hrane zahtijeva multidisciplinarni pristup, odnosno uključivanje etnološke metode u povijesna istraživanja. Početkom osamdesetih pojavljuju se radovi povjesničara koji se bave pitanjem ukusa, društvenosti, kulinarske inovativnosti i prehrambene drugosti, a koji proširuju područje istraživanja novim izvorima kao što su recepti, svečani jelovnici, ikonografski prikazi jela, kuharski tekstovi...

Do sredine devedesetih godina kulturalni pristup istraživanju prehrane postao je dominantan. Kulturalni obrat što su ga anticipirali radovi s početka osamdesetih, desetak je godina kasnije u istraživanja prehrane uveo teme koje problematiziraju pitanja identiteta, vrijednosnih sustava, društvene konstruiranosti ukusa, kao i simboličke, komunikacijske i reprezentacijske funkcije hrane (Scholliers 2007: 455). Povjesničari do kraja 1990-ih postaju osjetljivi na pitanja prehrambenog diskursa, odnosno njegove društvene konstruiranosti (iako Scholliers ističe da nisu prihvaćeni svi elementi lingvističkog preokreta kako ga je shvaćao Jacques Derrida (Scholliers 2007: 456)), no raspon tema ipak je uključivao istraživanja jezika, osobito reklama, i materijalne kulture. Amilien (2003) tako istražuje prehrambeni diskurs norveških restorana, odnosno regionalne različitosti u stvaranju slike o norveškoj kuhinji; Weiner (1996) piše o simboličnom značenju Coca-Cole u Drugom svjetskom ratu, dok Pyörälä (1994) analizira studentske stavove o konzumaciji alkohola u Finskoj i Španjolskoj. Analizirajući radove koji su ostvarili osobit utjecaj na razvoj i definiranje područja i metodologije istraživanja povijesti prehrane, poput danas kanonskih knjiga Davidsona (1999), Kiplea i Ornelasa (2000), Flandrina i Montanaria (1999), Super (2002) rezimira osnovne istraživačke perspektive koje uključuju pojmove difuzije, kuhinje, prehrane i drugosti, ističući da bi pojam Drugoga morao, uz difuziju, kuhinju i prehranu, biti ključan u istraživanjima prehrane. Pod pojmom difuzije Super objedinjuje različite teme kao što su kulinarske inovacije ili globalne promjene na tržištu hrane. Pitanje kuhinje (cuisine) također je shvaćeno kao rastezljiv pojam koji uključuje strukturu prehrane, ponašanje za stolom, prehrambene zabrane i profesionalne kuhare. Drugi temeljni pojam - prehrana, podrazumijeva probleme raspodjele hrane, društvene nejednakosti i gladi. Treći ključan istraživački zahtjev, onaj za istraživanjem drugosti podrazumijevao bi radove koji se bave konstrukcijama identiteta, kulturnim markerima i prehrambenim tabuima. Mogli bismo reći da je do 2000. godine povijest prehrane formirana kao multidisciplinarno istraživačko polje čiji razni pristupi i doprinosi ipak nisu rezultirali zajedničkim epistemiološkim aparatom, ali se mogu promatrati unutar istraživanja kulture. Scholliers (2007: 461) ističe dvije važne značajke istraživanja nakon 2000. godine, a to su bavljenje jezikom i pozdravljanje relativističkog pristupa (kao 
osobite karakteristike postmodernističkih teorija). Jezici ukusa ili kulinarski diskursi istražuju se s velikom pažnjom, nastavljajući tako trend kraja 1990ih, koji, doduše, još uvijek karakterizira manjak teorijskih radova. Najnovija istraživanja povijesti prehrane, kako ih analizira Priscilla Ferguson (2005) u svojem pregledu knjiga objavljenih u zadnjih šest godina, govore u prilog tomu da je povijest prehrane kompleksno polje te da debata o metodologiji i teoriji kao i o položaju unutar povijesnih znanosti još traje. Među radovima koje smatra ključnima za razumijevanje suvremenih povijesnih istraživanja prehrane ističe Abadovu knjigu (2002), koja opskrbu hranom u Parizu smješta u širi društveni kontekst, knjigu Serventia i Sabbana Pasta (2002) kao primjer kvalitetne komparativne analize pojedine namirnice, a potom se okreće knjizi Flandrina i Montanaria Food: A Cultural History (1999), koju smatra ključnom u prijelazu istraživačkog interesa s hrane na kuhinju, s kvantitativnih istraživanja na istraživanja kulture prehrane. Izvorima i ključnim konceptima današnje prehrambene historiografije Ferguson smatra prvenstveno socioekonomska istraživanja okupljena oko časopisa Annales, ali izdvaja tri utjecajna društvena koncepta: Eliasov civilizacijski proces, Veblenovu razmetljivu potrošnju te Bourdieuovu distinkciju. Anglosaksonska istraživanja, prema Ferguson (2005), svoju inspiraciju pronalaze u radovima Jacka Goodya (1982), Barbare Wheaton (1984), Stephana Mennella (1985) i Sidneya Mintza (1985) te se ne oslanjaju toliko na europsku sociološku tradiciju. Ferguson ipak zaključuje da se povijest prehrane ne može smatrati znanstvenom disciplinom i poljem budući da joj nedostaju zajedničke teorijske perspektive i metodologije te postavlja zahtjev za istraživanjem prehrambenih promjena, smatrajući hranu prije svega kretanjem (između vremena, mjesta, ljudi, klasa, zemalja i kultura). Scholliers u zaključku svoje analize dvadeset i pet godina istraživanja povijesti prehrane, kretanju dodaje pojam transformacije, smatrajući istraživanja prehrambenih sustava (prema engl. food systems) korisnim epistemiološkim okvirom koji može donijeti koherenciju različitim pristupima. Pojam prehrambenog sustava Scholliers prenosi iz političke ekonomije, podrazumijevajući pod njim jednostavnu sekvencu odnosa između proizvodnje, distribucije i potrošnje. No on bi trebao biti samo polazište koje se mora nadograđivati ispitivanjem odnosa svih dijelova. Pojednostavljeno rečeno, ključnim riječima trebali bismo smatrati značenje, reprezentaciju, kodove i konstrukcije identiteta, kojima Scholliers podupire svoj zahtjev za kulturalizacijom socioekonomske povijesti (2007: 467).

\section{PREHRAMBENI STUDIJI U SJEDINJENIM AMERIČKIM DRŽAVAMA}

Jednom kada je prehrana postala legitimna tema znanstvenog istraživanja, njezina novina, bogatstvo i raspon donijeli su beskrajnu korist znanstvenom 
svijetu - jer hrana spaja tijelo i dušu, jastvo i drugo, osobno i političko, materijalno i simbolično. Štoviše, kako hrana mijenja položaj od lokalnog i poznatog do globalnog i nepoznatog, tako se pretvara u potencijalni simbol straha i tjeskobe (Ferrieres 2005, prema Counihan i van Esterik 2008: 2) te moralnosti. (Telfer 2005, prema isto)

Prethodni pregled istraživanja prehrane u velikoj se mjeri odnosi na europsku istraživačku tradiciju. Pitanje pozicije prehrambenih studija, ${ }^{13}$ koji su u širem smislu shvaćeni kao istraživačka platforma u okviru društvenih i humanističkih studija, ${ }^{14}$ mnogo je aktualnije izvan europske tradicije koja se ne koleba o poziciji prehrambenih studija kao znanstvenoistraživačke paradigme. Razvoj prehrambenih studija u Sjedinjenim Američkim Državama, a donekle i u Kanadi, prvenstveno je povezan s osnivanjem studijskih programa, kako diplomskih tako i doktorskih (NYU, Boston, Indiana, Dillard University, New Orleans, Minnesota...). Usporedo s institucionalizacijom istraživanja prehrane, američka izdavačka produkcija literature o prehrani razlikuje akademsko i novinarsko pisanje o hrani, a doprinos potonjih (poput Michaela Pollana, Alice Waters, Erica Schlossera) u popularizaciji teme je nemjerljiv. Naslovi poput The Omnivore Dillemma (2007) Michaela Pollana ili Schlosserove knjige Fast food Nation (2001), kao i časopisa poput Gastronomice, ${ }^{15}$ hranu su učinili zanimljivom javnosti, ali još važnije, ukazali su na potrebu znanstvenog promišljanja pa tako Waren Belasco, jedan o ključnih američkih autora, ističe: "Hrana je osnovna životna potreba, najveći posao, [...] i užitak kojem se najčešće prepuštamo. Hrana predstavlja kreativnost i raznolikost" (Belasco 2002: 2). Prehrana se u američkoj istraživačkoj tradiciji, češće nego u europskoj, proučava u okviru globalnih ekonomskih uvjeta. Visok stupanj industrijalizacije američkih prehrambenih praksi, kao rezultat prehrambene revolucije koju neki autori ${ }^{16}$ smještaju na početak šezdesetih godina, stvorila je dvije posve odvojene kulinarske sfere - onu profesionalnu i onu kućansku, što je obilježavaju manjak vremena i kuharski prečaci. Prehrambene politi-

${ }^{13}$ Multidisciplinarna istraživanja (prije svega povijesna, kulturalna, bihevioristička, biološka i socioekonomska) prehrambenih praksi ukorijenjena u humanističkim i društvenim znanostima tek se od kraja 1990-ih, točnije od 1996. objedinjuju pod zajedničkim nazivnikom prehrambenih studija. Termin je prvi put iskorišten na Sveučilištu u New Yorku (New York University) prilikom osnivanja diplomskog i postdiplomskog programa na Odsjeku za Nutricionistiku, prehranu i hotelski menadžment (McIntosh i Nestle 2010).

${ }^{14}$ Nutricionistička i medicinska istraživanja namjerno su ispuštena iz ovoga rada iako se i te discipline uključuju u, uglavnom, multidisciplinarna antropološka istraživanja prehrane.

15 Gastronomica, The Journal of Food and Culture nastala je iz želje objedinjavanja popularnog i znanstvenog pisanja o hrani i piću. Desetogodišnja urednica Gastronomice Darra Goldstein objašnjava: "Maštala sam o časopisu gdje bi se mogli objavljivati i temeljita znanstvena istraživanja kao i popularni tekstovi o hrani" (Smith, Pichler i Goldstein 2010: 328).

${ }^{16}$ O kulinarskoj revoluciji što se odvijala u privatnim kuhinjama 50-ih i 60-ih godina 20. stoljeća vidi Shapiro (2005). 
ke, globalizacija i industrijalizacija prehrane i s njima povezani prehrambeni strahovi, najčešće su teme američkih autora. Pitanje popularnosti hrane u medijima, ali i zdravstveni problemi povezani s pretilošću rezultirali su sinergijom različitih znanstvenih perspektiva (nutricionizam, sociologija, antropologija, medicina). Nestle (McIntosh i Nestle 2010) početni impuls ozbiljnijeg bavljenja hranom u američkoj akademskoj zajednici povezuje s objavljivanjem niza enciklopedija koje su se bavile prehranom. Među njima Nestle ističe The Oxford Companion to Food (1999), Cambridge World History of Food (2000), Encyclopedia of Food and Culture (2004), Oxford Encyclopedia of Food and Drink in America (2004). Legitimizacija prehrambenih studija odvija se u otprilike isto vrijeme kao i u Europi, a sveučilišne naklade daju velik poticaj bavljenju kulturom prehrane (spomenimo tek neke poput University of California Press, Columbia University Press, University of Illinois...), ali se prehrambeni studiji pozicioniraju, ili to barem nastoje, kao društveni pokret s određenom odgovornošću i jasnim htijenjem za vlastitom korisnošću (Clapp 2008; de la Peña 2011; Bilterkoff 2011; Bentley 2011; McIntosh i Nestle 2010). Prehrambene studije, prema McIntoshu, treba shvatiti kao intelektualni pokret koji se približava kulturalnim studijima, a nalazi se između društvenih i humanističkih znanosti (McIntosh i Nestle 2010: 169), pritom spominjanje kulturalnih studija zapravo otkriva temeljni zahtjev za interdisciplinarnošću. No, McIntosh ipak ističe kolebanje svojstveno američkim prehrambenim studijima te priznaje zahtjev za vidljivošću istraživanja i utjecajem na prehrambene politike. Tako Nestle navodi niz prehrambenih pokreta koji svoju pozadinu mogu imati u radovima znanstvenika. Prehrambeni aktivizam (prema engl. food advocacy), kako ga Nestle naziva (isto: 164), možemo promatrati kroz nekoliko jasno artikuliranih tema kao što su organska hrana, lokalna proizvodnja, spora hrana, dobrobit životinja, pretilost, školska hrana... Belasco priznaje da baveći se prehranom osjeća potrebu biti istodobno praktičan i koristan (2011: 302). Pa iako je hrana "ključna u konstrukciji naših osobnih i kulturnih identiteta” (Belasco 1999: 27) impuls za korisnošću navodi na bavljenje osnovnim prehrambenim problemima $u$ SAD-u, a to je prvenstveno problem pretilosti. Od kraja sedamdesetih medicinska istraživanja (kojima tema pretilosti prvenstveno pripada) okreću se kroničnim bolestima i proučavanju životnih stilova. "Potraga za zdravljem postala je sve važnija preokupacija američke srednje klase”, ističe Belasco (2011: 307). Upravo je prehrana shvaćena kao osnova održavanja zdravlja (Lupton i Peterson 1996; Crawford 2006), pri čemu su dijetetski ideali postali unosnim područjem novih medicinskih, farmaceutskih i nutricionističkih istraživanja. Shvaćanje da prehrambeni ideali nisu objektivni, već ideološki nabijeni te da se izbor ispravne prehrane oblikuje putem kulture i sustava vrijednosti otvorilo je prostor znanstvenicima društvenih i humanističkih znanosti, a time i potaklo pitanje njihove društvene odgovornosti (Bilterkoff 
2011: 308) ${ }^{17}$ Pitanje odgovornosti, odnosno primjenjivosti humanističkih znanosti aktualno je i u američkoj i europskoj akademskoj zajednici. Značajnije bavljenje temama poput pretilosti ili bacanja hrane (prema engl. food waste) jasno pokazuje nastojanje za primjenjivošću društvenih i humanističkih istraživanja. Okretanje temama koje izravno korespondiraju s aktualnim društvenim problemima jedan je od mogućih odgovora na pitanje o nekorisnosti humanistike. Jednako tako, društveno angažirani pokreti i aktivističke inicijative, povezane s istraživanjem prehrane, mogu biti izravno motivirane spoznajama društvenih i humanističkih znanosti.

\section{ZAKLJUČAK}

Istraživanja prehrane unazad desetak godina postala su jedno od najpropulzivnijih znanstvenih područja. Od posve marginalne i trivijalne teme, koja je čak mogla i ugroziti napredak znanstvene karijere (Belasco u svojem tekstu Why Food Matters? preporuča mladim znanstvenicima zainteresiranima za povijest prehrane da potisnu svoj interes do druge knjige (1999: 28)), prehrana je postala jedan od najvidljivijih novih znanstvenih interesa. Ne samo da je popularnost hrane danas veća nego ikada prije, pri čemu govorimo o njezinoj nikad većoj prisutnosti u medijima, nego nikada prije nije izazivala toliko strahova i posve oprečnih stavova. Znanstvenici koji se bave tim područjem prema vlastitom su sudu sretni. Belasco tako naglašava da nam drugi zavide jer istražujemo nešto i zanimljivo i zabavno. Čini se da je danas odlično vrijeme za istraživanje u okviru paradigme prehrambenih studija, jer kako duhovito (autoironično?) ističe dugogodišnja urednica časopisa Gastronomica Darra Goldstein: "Istraživanja hrane nisu samo prihvatljiva nego su i chic!" (Smith, Pilcher i Goldstein 2010: 326).

Jednako kao što se unutar povijesnih znanosti povijest prehrane još uvijek ne smatra zasebnom disciplinom, zbog nepostojanja zajedničke metodologije ili teorijske perspektive, tako se i unutar samih prehrambenih studija ne može govoriti o jedinstvenoj znanstvenoj disciplini. Pojam prehrambenih studija treba shvatiti kao zajednički nazivnik znanstvenih doprinosa različitih disciplina. Istodobno valja istaknuti da je prehrambenim studijima inherentno nastojanje traženja rješenja za aktualne društvene probleme vezane uz hranu. Isticanje tema poput prehrambenih strahova, ${ }^{18}$ poremećaja u prehrani, gladi, alternativnih načina uzgoja i distribucije hrane i sl. upućuje

\footnotetext{
${ }^{17}$ Više u Belasco et al. (2011).

${ }^{18}$ Pod pojmom prehrambenih strahova obično se podrazumijevaju suvremene preokupacije vezane uz nepovjerenje prema komercijalnom uzgoju hrane kao i prema prehrambenoj industriji općenito. Time se donekle objašnjava uspon različitih prehrambenih pokreta koji zagovaraju, primjerice, organsku hranu, povratak starinskim bakinim kuhinjama i sl.
} 
na zaključak da je u prehrambenim studijima unaprijed odbačeno pitanje korisnosti humanističkih i društvenih znanosti. Ujedno, trenutna pozicija istraživanja kulture prehrane, odnosno nastanak prehrambenih studija, također je rezultat društvenih promjena zadnjih desetljeća. Popularnost hrane u medijskoj kulturi podudara se s njezinom akademskom popularnošću, pa možemo reći da je upravo to odnos o kojem bi valjalo dalje razmišljati.

\section{NAVEDENA LITERATURA I IZVORI}

Abad, Reynald. 2002. Le Grand Marche'. L'Approvisionnement alimentaire de Paris sous l'Ancien régime. Paris: Fayard.

Amilien, Virginie. 2003. "A View of Eating Out in Norway. Rise and Meaning of Restaurants". U Eating Out in Europe. Picnics, Gourmet Dining and Snacks since the Late Eighteenth Century. Marc Jacobs i Peter Scholliers, ur. Oxford, New York: Berg Publishers.

Arnott, Margaret L., ur. 1975. Gastronomy. The Anthropology of Food and Food Habits. Hague: Mouton Publishers.

Barthes, Roland. 2008. "Toward a Psychosociology of Contemporary Food Consumption". U Food and Culture. A Reader. Carole Counihan i Penny Van Esterik, ur. New York, London: Routledge, 28-35.

Barthes, Roland. 2009. Mitologije. Zagreb: Naklada Pelago.

Belaj, Melanija. 2010. Etnološki i kulturnoantropološki pristup kulturi obiteljske proizvodnje i uživanja alkohola. [Doktorska disertacija]. IEF rkp 1979.

Belaj, Melanija. 2011. "Family Economy. Women and the Production of Alcoholic Beverages". U Spiritual Paractices and Economic Realities. Feminist Challenges. Renata Jambrešić Kirin i Sandra Prlenda, ur. Zagreb: Centar za ženske studije Zagreb, Institut za etnologiju i folkloristiku, 303-317.

Belaj, Melanija. 2013. "Food Research in Croatian Ethnology". Traditiones 42/1: 165-172. [http://dx.doi.org/10.3986/Traditio2013420109]

Belasco, Warren. 1999. "Why Food Maters?" Culture and Agriculture 21/1: 27-34. [http:// dx.doi.org/10.1525/cag.1999.21.1.27]

Belasco, Warren i Philip Scranton, ur. 2002. Food Nations. Selling Taste in Consumer Societies. NewYork,London:Routledge.Dostupnona:http://books.google.hr/books?id=ZZMy7hJeT_ $\mathrm{EC} \&$ printsec $=$ frontcover $\# \mathrm{v}=$ onepage $\& \mathrm{q} \& \mathrm{f}=$ false (pristup 22. 11. 2012.).

Belasco, Waren et al. 2011. "The Frontiers of Food Studies". U Food, Culture and Society 14/3: 301-314.

Bentley, Amy. 2011. "The Frontiers of Food Studies". Food, Culture and Society 14/3: 304-306.

Bilterkoff, Charlotte. 2011. "The Frontiers of Food Studies". Food, Culture and Society 14/3: 306-308.

Bourdieu, Pierre. 2005. "Taste of Luxury, Taste of Necessity”. U The Taste Culture Reader. Experiencing Food and Drink. Carolyn Korsmeyer, ur. Oxford, New York: Berg, 72-78.

Bourdieu, Pierre. 2011. Distinkcija, Društvena kritika suđenja. Zagreb: Antibarbarus.

Braudel, Fernand. 1992. Strukture svakidašnjice. Zagreb: August Cesarec. 
Braziel, Jana Evans i Kathleen LeBesco. 2001. Bodies out of Bounds. Fatness and Transgression. Oakland: University of California Press.

Brillat Savarin, Anthelme. 1998. Fiziologija okusa. Zagreb: Dora Krupićeva.

Burnett, John. 1989. Plenty and Want. A Social History of Diet in England from 1815 to the Present Day. [3. izdanje]. Oxon: Routledge.

Clapp, Jennifer. 2008. "A Global Outlook on Food Studies". Food, Culture and Society 11/3: 282286. [http://dx.doi.org/10.2752/175174408X347865]

Cockburn, Alexander. 1977. "Gastro-porn". The New Yorker Review of Books. Dostupno na: http://www.nybooks.com/articles/archives/1977/dec/08/gastro-porn/?pagination$=$ false (pristup 17. 10. 2012.).

Counihan, Carole i Penny van Esterik, ur. Food and Culture. A Reader. New York, London: Routledge.

Crawford, Robert. 2006. "Health as Meaningful Practice". Health. An Interdisciplinary Journal for the Social Study of Health, Medicine and Illness 10/4: 401-20.

Davidson, Alan. 1999. The Oxford Companion to Food. Oxford: University Press.

De la Peña, Carolyn. 2011. "The Frontiers of Food Studies". Food, Culture and Society 14/3: 311-313.

Douglas, Mary. 1975. "Deciphering a Meal". U Implicit Meanings. London, Boston: Routledge\&Kegan Paul, 249-276.

Douglas, Mary. 1987. Constructive Drinking. London: Routledge.

Dukheim, Emile. 2008. Elementarni oblici religijskog života. Totemistički sustav u Australiji. Zagreb: Jesenski i Turk, Hrvatsko sociološko društvo.

Elias, Norbert. 1983 [1969]. The Court Society. Oxford: Blackwell.

Elias, Norbert. 1996. O procesu civilizacije. Sociogenetska i psihogenetska istraživanja. Zagreb: Izdanja Antibarbarus.

Engels, Friedrich. 1952. Položaj radničke klase u Engleskoj. Zagreb: Kultura.

Fenton, Alexander i Trevor M. Owen. 1981. Food in Perspective. Proceedings of the Third International Conference on Ethnological Food Research. Edinburgh: John Donald Publishers.

Ferguson, Priscilla. 2005. "Eating Orders. Markets, Menus and Meals". Journal of Modern History 77/3: 679-700. [http://dx.doi.org/10.1086/497720]

Fiddes, Nick. 2002. Meso. Prirodni simbol. Zagreb: Jesenski i Turk.

Fischler, Claude. 1990. "Food Habits, Social Change and the Nature/Culture Dilemma". Social Science Information 19/6: 937-953. [http://dx.doi.org/10.1177/053901848001900603]

Flandrin, Jean-Louise i Massimo Montanari. 1999. Food. A Cutural History from Antiquity to the Present. New York: Columbia University Press.

Gavazzi, Milovan. 1978a. "Seoska prehrana u Jugoslaviji". U Vrela i sudbine narodnih tradicija. Zagreb: Sveučilišna naklada Liber, 108-114.

Gavazzi, Milovan. 1978b. “Oko podrijetla jednog blagdanskog peciva južnih Slavena”. U Vrela i sudbine narodnih tradicija. Zagreb: Sveučilišna naklada Liber, 38-44.

Goody, Jack. 1982. Cooking, Cuisine, and Class. A Study in Comparative Sociology. Cambridge, New York: Cambridge University Press. [http://dx.doi.org/10.1017/CB09780511607745]

Goody, Jack. 2008. "The Recipe, the Prescription, and the Experiment". U Food and Culture. A Reader. Carole Counihan i Penny van Esterik, ur. New York, London: Routledge, 78-90.

Harris, Marvin. 1986. Good to Eat. Riddles of Food and Culture. New York: Simon and Schuster. 
Ivanišević, Jelena. 2008. "Kada kuhaju bake... Tradicija i povijest u dvjema bakinim kuharicama". Narodna umjetnost 45/2: 153-164.

Ivanišević, Jelena. 2011. "Nostalgične kuharice i kulinarski eseji. Literarna arheologija Veljka Barbierija”. Književna smotra: časopis za svjetsku književnost 160/2: 123-134.

Ivanišević, Jelena. 2014. Od kuharice do književnosti. Hrvatski kulinarski i gastronomski narativi. Zagreb: IEF rkp 2048.

Jobse van - Putten, Jozien. 1989. Van pekelvat tot diepvrieskist. Interviews en beschouwingen over de huishoudleijke conservering op het Nederlandse platteland in de eerste helft van de twintigste eauw (From prickle-tub to freezer: Interviews and observations on household preservation int he Dutch countryside int he first half od the twentieth century). Amsterdam: Meertens-Instituut.

Kiple, Kenneth F. i Kriemhild C. Ornelas, ur. 2000. The Cambridge World History of Food. Cambridge: University Press.

Kisbán, Esther. 1986. "Food Habits in Change. The Example of Europe". U Food in Change. Eating Habits from the Middle Ages to the Present Day. Alexander Fenton i Esther Kisbán, ur. Edinburgh: John Donald, 2-11.

Kocković, Tanja. 2006. "Truffle-hunting in Istria". U Mediterranean Food. Concepts and Trends/ proceeding of the 15th International Ethnological Food Research Conference. Zagreb: Institut za etnologiju i folkloristiku, 53- 65.

Lévi Strauss, Claude. 1977. Strukturalna antropologija. Zagreb: Stvarnost.

Lévi Strauss, Claude. 2008. "The Culinary Triangle". U Food and Culture. A Reader. Carole Counihan i Penny van Esterik, ur. New York, London: Routledge.

Lupton, Deborah i Alan Peterson. 1996. The New Public Health. Health and Self in the Age of Risk. London: Routledge.

Lysaght, Patricia i Nives Ritig Beljak, ur. 2006. Mediterranean Food: Concepts and Trends/proceeding of the 15th International Ethnological Food Research Conference. Zagreb: Institut za etnologiju i folkloristiku.

McIntosh, Alex W. i Marion Nestle. 2010. "Writing the Food Studies Movement”. Food, Culture and Society 13/2: 160-179.

Mennell, Stephan, Anne Murcott i Aneke H. van Oterloo. 1989. Prehrana i kultura - sociologija hrane. Zagreb: Jesenski i Turk, Hrvatsko sociološko društvo.

Mennell, Stephan. 1985. All Manners of Food. Eating and Taste in England and France from the Middle Ages to the Present. Oxford, New York: Blackwell.

Mintz, Sidney W. 1985. Sweetness and Power. The Place of Sugar in Modern History. Dostupno na: https://www.scribd.com/doc/139127426/Mintz-Sweetness-and-Power\#scribd (pristup 21. 10. 2015.).

Murcott, Anne, Warren Belasco i Peter Jackson, ur. 2013. The Handbook of Food Research. London: Bloomsbury Academic.

Orlić, Ivona. 2009. "Tradicijska kultura prehrane kao turistička atrakcija. Branje voća i samoniklog bilja u Istri". Turist kao gost - prilozi kulinarskom turizmu. Nives Rittig-Beljak i Melanija Belaj, ur. Zagreb: Institut za etnologiju i folkloristiku, 7-21.

Orlić, Ivona. 2013. Istra kroz tri generacije. Između svakodnevne konstrukcije identiteta i turističkog proizvoda. Pazin: Etnografski muzej Istre.

Orwell, George. 1945. In Defence of English Cooking. Dostupno na: http://orwell.ru/library/ articles/cooking/english/e_dec (pristup 11. 10. 2013.).

Pollan, Michael. 2007. The Omnivore's Dilemma. London, Berlin, New York: Bloomsbury. 
Pyörälä, Eva. 1994. "Drinking, Drunkenness and Alcoholic Beverages in Spain and Findland. A Study of Vocabulary Among young Adults". Food and Foodways 6/1: 43-56. [http://dx.doi. org/10.1080/07409710.1994.9962024]

Radić, Antun. 1897. Osnova za sabiranje i proučavanje građe o narodnom životu. (Zbornik za narodni život i običaje Južnih Slavena, 2). Zagreb: Jugoslavenska akademija znanosti i umjetnosti.

Richards, Audrey. 1932. Hunger and Work in a Savage Tribe. A Functional Study of Nutrition among the Southern Bantu. London: Routledge.

Richards, Audrey. 1937. The Food and Nutrition of African Natives. London: International Institute of African Languages and Cultures.

Richards, Audrey. 1939. Land, Labour, and Diet ibn Northern Rhodesia. Oxford: Oxford University Press.

Riesman, David. 1965. Usamljena gomila. Studija o promeni američkog karaktera. Beograd: Nolit.

Rittig-Beljak, Nives. 1996. "Croatian Exiles from Vojvodina. Between War Memories and War Experience”. U War, Exile, Everyday Life. Cultural Perspectives. Renata Jambrešić Kirin i Maja Povrzanović, ur. Zagreb: Institute of Ethnology and Folklore Research, 173-179.

Ritig-Beljak, Nives. 2000. "How to Appease One’s Hunger in Exile". Narodna umjetnost 37/1: 97-113.

Rittig-Beljak, Nives. 2005. "Rječničko blago Gazophylaciuma (1740) u povijesti hrvatskog kulinarstva". Gazophylacium: časopis za znanost, umjetnost, gospodarstvo i politiku 10/1-2: 205-213.

Rittig-Beljak, Nives i Mirjana Randić, 2006. Svijet hrane u Hrvatskoj. Zagreb: Etnografski muzej Zagreb.

Rittig-Beljak, Nives i Melanija Belaj, ur. 2009. Turist kao gost. Prilozi kulinarskom turizmu. Zagreb: Institut za etnologiju i folkloristiku.

Rousseau, Signe. 2012. Food Media. Celebrity Chefs and the Politics of Everyday Interference. London, New York: Berg.

Schlosser, Eric. 2001. Fast Food Nation. The Dark Side of the All-American Meal. Boston: Houghton Mifflin.

Scholliers, Peter. 2007. "Twenty Five Years of Studying un Phénomène social total; Food Writing on Europe in the $19^{\text {th }}$ and $20^{\text {th }}$ Century". Food, Culture and Society 10/3: 450-471. [http://dx.doi.org/10.2752/155280107X239881]

Scholliers, Peter i Kyri W. Claflin, ur. 2012. Writing Food History, a Global Perspective. London: Bloomsbury.

Serventi, Silvano i Francoise Saban. 2002. Pasta. The Story of Universal Food. New York: Columbia University Press.

Shapiro, Laura. 2005. Something from the Oven. Reinventing Dinner in the 1950s America. New York: Penguin.

Simmel, Georg. 1910 “Soziologie der Mahlzeit”. Dostupno na: http://dtserv3.compsy.uni-jena. de/ss2013/allgsoz_uj/48755669/content.nsf/Pages/FBBF69C020AAFBB9C1257B2C00 5C421A/\$FILE/Georg\%20Simmel_\%20Soziologie\%20der\%20Mahlzeit.pdf (pristup 25. 9. 2015.).

Smith, Andrew, Jeffrey M. Pilcher i Darra Goldstein. 2010. "Food Scholarship and Food Writing". Food, Culture and Society 13/3: 320-329. [http://dx.doi.org/10.2752/175174410X $12699432700827 \mathrm{~s}]$ 
Super, John C. 2002. "Review Essay. Food and History". Journal of Social History 36/1: 165178. [http://dx.doi.org/10.1353/jsh.2002.0110]

Teuteberg, H. J. 1986. "Period and Turning Points in the History of European Diet. A Preliminary Outline of Problems and Methods". U Food in Change. Eating Habits from the Middle Ages to the Present Day. Alexander Fenton i Esther Kisbán, ur. Edinburgh: John Donald, 11-23.

van Oterloo, Aneke H. 1990. Eten en eelust in Nederland 1840-1990. Amsterdam: Bert Bakker.

van Winter, Johanna Maria. 2006. "Sugar - Spice of the Crusaders". U Mediterranean Food. Concepts and Trends/ proceeding of the 15th International Ethnological Food Research Conference. Patricia Lysaght i Nives Ritig Beljak, ur. Zagreb: Institut za etnologiju i folkloristiku, 301-309.

Veblen, Thorstein. 2008. Teorija dokoličarske klase. Novi Sad: Mediterran Publishing.

Voskuil, Johannes Jacobus. 1983. "De veg naar luilekkerland" (The road to the land of Cockaigne). Bijdragen en Mededelingen betreffebde de Geschiedenis der Nederlanden 95/3: 460-482.

Wiegelmann, Günter. 2006. Alltags und Festspeisen. Wandel und gegenwärtige Stellung. Münster: Waxmann.

Weiner, Mark. 1996. "Consumer Culture and Participation Democracy. The Story of Coca-Cola during World War II". Food and Foodways 6/2: 109-129. [http://dx.doi.org/10.1080/074 09710.1996.9962033]

Wheaton, Barbara. 1984. Savouring the Past. The French Kitchen Table and from 1300 to 1789. London: Chatto \& Windus.

\section{THE DEVELOPMENT OF FOOD STUDIES: THE CONTRIBUTIONS OF SOCIOLOGY, CULTURAL ANTHROPOLOGY, ETHNOLOGY AND HISTORY}

\section{SUMMARY}

This paper gives an overview of the relevant research in the fields of cultural anthropology, ethnology, sociology and history of food that had an impact on the development of food studies, a platform that brings together research in food culture from the viewpoint of a variety of scholarly disciplines and subdisciplines. The paper also highlights the growing impossibility of writing about food from a single disciplinary perspective, thus underlining the need for interdisciplinary research of food in different contexts.

Keywords: food studies, food, ethnology and cultural anthropology of food, sociology of food, historical food studies 